\title{
Expression of Telomerase Activity, Human Telomerase RNA, and Telomerase Reverse Transcriptase in Gastric Adenocarcinomas
}

\author{
Jinyoung Yoo, M.D., Ph.D., Sonya Y. Park, Seok Jin Kang, M.D., Ph.D., Byung Kee Kim, M.D., Ph.D., \\ Sang In Shim, M.D., Ph.D., Chang Suk Kang, M.D., Ph.D. \\ Department of Pathology, St. Vincent's Hospital, Catholic University, Suwon, South Korea
}

Telomerase is an RNA-dependent DNA polymerase that synthesizes TTAGGG telomeric DNA onto chromosome ends to compensate for sequence loss during DNA replication. It has been detected in $85-90 \%$ of all primary human cancers, implicating that the telomerase seems to be reactivated in tumors and that such activity may play a role in the tumorigenic process. The purpose of this study was to evaluate telomerase activity, human telomerase RNA (hTR), and telomerase reverse transcriptase (TERT) in stomach cancer and to determine their potential relationships to clinicopathologic parameters. Frozen and corresponding methacarn-fixed paraffinembedded tissue samples were obtained from 51 patients with gastric adenocarcinoma and analyzed for telomerase activity by using a TRAPeze ELISA kit. Tissue sections of all the samples were further investigated for hTR and TERT by in situ hybridization and a sensitive immunohistochemical technique, respectively. Telomerase activity was detected in 37 (73\%) tumors. Telomerase positivity from methacarn-fixed paraffin blocks was found to be $35 \%$ of that from frozen tissues. hTR was overexpressed in $46(90 \%)$ samples: $33 / 37(89 \%)$ with and 13/14 (93\%) without telomerase activation. Expression of TERT was demonstrated in $40(78 \%)$ cases: $30 / 37(81 \%)$ with and $10 / 14(71 \%)$ without telomerase. Telomerase activity correlated well with depth of invasion $(P=.037)$ and tumor differentiation $(P=.022)$, whereas hTR significantly correlated with nodal metastasis $(P=.047)$ and tumor size $(P$ $=.023)$. These data suggest that reactivated telomerase may play a significant role in the tumorigen-

Copyright (C) 2003 by The United States and Canadian Academy of Pathology, Inc.

VOL. 16, NO. 7, P. 700, 2003 Printed in the U.S.A.

Date of acceptance: May 1, 2003.

Supported by a grant from Samkwang Research Laboratories.

Address reprint requests to: Seok Jin Kang, M.D., Ph.D., Department of

Pathology, St. Vincent's Hospital, Catholic University, Suwon, Kyungkido,

South Korea 442-723; fax: 8231-244-6786; e-mail: sjkang@vincent.cuk.ac.kr.

DOI: 10.1097/01.MP.0000077517.44687.B6 esis of gastric cancer and may reflect, along with enhanced hTR, the malignant potential of the tumor. It is noteworthy that methacarn-fixed tissue cannot as yet substitute for the frozen section in the TRAP assay.

KEY WORDS: hTR, Stomach cancer, Telomerase, TERT.

Mod Pathol 2003;16(7):700-707

Recent studies of stomach cancer have been directed toward gaining a better understanding of tumor biology. Molecular analysis has suggested that alterations in the structures and functions of oncogenes and tumor suppressor genes, genetic instability, as well as the acquisition of cell immortality may be of relevance in the pathogenesis of these tumors (1-3). Telomerase activation is believed to be crucial in most immortal cells and cancer cells $(4,5)$; however, its clinicopathologic significance in gastric cancer and the details of the mechanisms regulating telomerase activity remain to be clarified.

Eukaryotic chromosomes are capped with repetitive telomere sequences that protect the chromosome ends against exonucleases and ligases, thus preventing fusion, recombination, and degradation $(6,7)$. In human chromosomes, telomeres consist of thousands of copies of the nucleotide sequence 5'-TTAGGG-3' ranging from 5-20 kb in length. Telomeres shorten in somatic cells with successive cell divisions because of the inability of the DNA polymerase complex to replicate the 5 ' end of the lagging strand $(8,9)$. Germline cells compensate for this end-replication problem by expression of the enzyme telomerase, which is an RNA-dependent DNA polymerase that synthesizes telomeric repeats and incorporates them onto the 3' end of existing telomeres (10). Telomerase activity has been identified in immortal cells, cancer cells, and germ cells, but not in normal somatic cells (11-20). The reactivation of telomerase thus appears to be associated 
with unlimited replicative potential, resulting in the immortalization of cells. Human telomerase RNA (hTR) is one of the major subunits of telomerase, encompassing 11 nucleotides (5'-CUAACCCUAAC) complementary to the human telomeric repeats (21). Telomere shortening and eventual cell death were observed in yeast cells that were deleted for the telomerase RNA component $(22,23)$. Other antisense experiments with hTR indicated that telomerase inhibition may lead to telomere shortening and cell death in human tumor cell lines (21). Expression of telomerase reverse transcriptase (TERT), a catalytic subunit component, has been reported in telomerase-positive cell lines but not in telomerase-negative primary fibroblasts $(24,25)$, yet the correlation between telomerase activity and expression of hTR and TERT has not been well documented in clinical samples.

To investigate the expression of telomerase, hTR, and TERT in stomach cancer and to determine their potential relationships with clinicopathologic parameters, we analyzed 51 samples for telomerase activity, hTR, and TERT with the use of a telomerase (TRAP) assay, in situ hybridization (ISH), and immunohistochemistry, respectively.

The TRAP is a sensitive and efficient polymerase chain reaction (PCR)-based telomerase activity detection method $(4,26,27)$, but its limitation is the need for either fresh or frozen tissues for the reaction. Methacarn-fixed paraffin-embedded tissues were found to be suitable for molecular analysis (28-30). Methacarn fixation is recommended as a valuable approach for routine application, considering its advantages for molecular studies at the mRNA level and for immunohistochemical detection of proteins. To determine whether methacarnfixed paraffin-embedded tissues can replace cryostat sections for the TRAP assay, duplicate studies were performed using both frozen and matched methacarn-fixed specimens.

\section{MATERIAL AND METHODS}

A total of 51 stomach cancer tissues were obtained from patients who underwent gastrectomy at Catholic University St. Vincent's Hospital, South Korea. Upon surgical removal, tumor tissues were immediately frozen in liquid nitrogen and stored at $-80^{\circ} \mathrm{C}$ until they were subjected to TRAP assay. To compare unfixed frozen tissue samples with methacarn-fixed tissues, a piece of the specimen from the same area taken for the frozen section used as TRAP assay was fixed in methacarn for 1 hour at $4^{\circ} \mathrm{C}$, dehydrated three times for 1 hour each in fresh $100 \%$ ethanol at $4^{\circ} \mathrm{C}$, placed in xylene once for 1 hour and then three times for 30 minutes at room temperature, and immersed in hot paraffin $\left(60^{\circ} \mathrm{C}\right)$ three times for 1 hour. Additional tissue specimens were fixed in $10 \%$ phosphate-buffered neutral formalin, routinely processed, and stained with hematoxylin and eosin for the final diagnosis. All of the histologic sections were reviewed and categorized according to International Union Against Cancer tumor-node-metastasis (UICCTNM) classification. Ten samples obtained from adjacent normal tissues were run in parallel for detection of telomerase activity.

\section{Telomerase Assay}

Telomerase assay was performed as described previously. Each frozen sample was thawed to $-20^{\circ}$ $\mathrm{C}$ and cryosectioned using a Cryostat apparatus (Leica, Inc., Deerfield, IL). Ten consecutive 10- $\mu \mathrm{m}$ sections were obtained and suspended in ice-cold $1 \times$ CHAPS lysis buffer (10 mm Tris- $\mathrm{HCl}, \mathrm{pH} 7.5,1$ mм $\mathrm{MgCl}_{2}$, 1 mм EGTA, $0.1 \mathrm{~mm}$ benzamidine, $5 \mathrm{~mm}$ $\beta$-mercaptoethanol, $0.5 \%$ CHAPS, and $10 \%$ glycerol) containing RNase inhibitor at a final concentration of 100-200 U/mL. After 30 minutes of incubation on ice, the lysate was centrifuged at 14,000 $\times$ $g$ for 25 minutes at $4^{\circ} \mathrm{C}$, and the supernatant was transferred into a fresh tube. Protein concentrations of the tissue extract were measured by the Bradford method (Bio-Rad, Hercules, CA), and an aliquot of extract containing $6 \mu \mathrm{g}$ of protein was used for each TRAP assay. For RNA quality control, the lysate (total, $60 \mu \mathrm{g}$ of protein extract) was mixed with TRIzol (GIBCO-BRL, Gaithersburg, MD) and chloroform and then centrifuged. RNA was precipitated from the aqueous phase by the addition of isopropanol, washed and dissolved in RNase-free water. RNA was electrophoresed in formamide- $1 \%$ agarose gel. The remaining extract was immediately stored frozen at $-80^{\circ} \mathrm{C}$.

For the TRAP assay, TRAPeze ELISA (Introgen Co., Purchase, NY), a telomerase detection kit, was used according to the manufacturer's instructions with minor modifications. Fifty $\mu \mathrm{L}$ of reaction mixture containing $1 \mu \mathrm{g}$ of protein extract, $10 \mu \mathrm{L}$ of $5 \times$ TRAP reaction mix (Tris buffer, primers, biotinylated TS primer and RP primer, dNTPs and DNP$\mathrm{dCTP}$, and oligomer mix for amplification of 36-bp internal control band), and 2 units of Taq DNA polymerase (Life Technologies, Gaithersburg, MD), was incubated for 30 minutes at $30^{\circ} \mathrm{C}$ and subsequently subjected to two-step PCR at $94^{\circ} \mathrm{C}$ for 30 seconds and $55^{\circ} \mathrm{C}$ for 30 seconds for 33 cycles. Analysis of each sample consisted of three assays: one with a test extract of $1 \mu \mathrm{g}$, one with $0.2 \mu \mathrm{g}$ of protein, and one with a heat-inactivated lysate at $85^{\circ} \mathrm{C}$ for 10 minutes before the assay. For a primerdimer/PCR contamination control, $2 \mu \mathrm{L}$ of $1 \times$ CHAPS lysis buffer was substituted for the extract. Each set of experiments also included telomerase- 
positive control cell extract and PCR/ELISA-positive control supplied in the kit. Nonradioactive detection of the telomerase products was performed by ELISA protocol. TRAP products tagged with biotin and DNP residues were immobilized onto streptavidin-coated microtiter plates via biotinstreptavidin interaction and then detected by antiDNP antibody conjugate to horseradish peroxidase (HRP). The amount of TRAP products was determined by means of the HRP activity using substrate 3,3',5,5'-tetramethylbenzidine (TMB) and subsequent color development. For direct visualization of the TRAP ladder and confirmation of the ELISA results, all the PCR products were also electrophoresed on a $12.5 \%$ nondenaturing polyacrylamide gel, which was then stained with ethidium bromide.

Thin sections from methacarn-fixed paraffinembedded tissue specimens were analyzed in parallel for the presence of telomerase activity to compare the results obtained from the frozen tissue samples. Briefly, 10 sections (10- $\mu$ m thick) were cut from the selected paraffin blocks and stained with hematoxylin and eosin. All of the slides (lacking coverslips) were used for microdissection. Precisely identified tumor tissue was procured with care by use of a needle to assure that $\geq 90 \%$ of the recovered cells were tumor as opposed to unremarkable connective tissue elements, necrotic debris, or inflammatory or hemorrhagic cell populations. The cells were transferred to a sterile Eppendorf tube and suspended in ice-cold $1 \times$ CHAPS lysis buffer. Remaining procedures were the same as described above for frozen tissue sections.

\section{ISH for hTR}

ISH for hTR expression was performed using formalin-fixed, paraffin-embedded tumor tissue sections that contained $>90 \%$ tumor tissue. Fluoresceinated oligonucleotide probes for the hTR and ISH detection kit were purchased from Innogenex (San Ramon, CA). Deparaffinized and rehydrated $5-\mu \mathrm{m}$ tissue sections were treated with RNase-free proteinase $\mathrm{K}$ for 15 minutes at room temperature in a humidity chamber. After a 5-minute rinse in sterile deionized water containing $0.2 \%$ RNase block, postfixation with $1 \%$ formaldehyde/RNase-free PBS was performed for 10 minutes at room temperature. Slides were dipped in deionized water containing $0.2 \%$ RNase block. For the hybridization reaction, tissue sections were incubated overnight at $37^{\circ} \mathrm{C}$ in $20-40 \mu \mathrm{L}$ of the fluoresceinated probe sealed with a coverslip. After hybridization, the sections were washed twice in $2 \times$ PBS-Tween and incubated in power block reagent for 5 minutes at room temperature to remove any probes that were unbound or nonspecifically bound to the tissue section. Subsequent immunohistochemical proce- dure detected the probe-target hybrid. This included incubating slides with the sequential addition of mouse anti-fluorescein antibody, biotinylated anti-mouse antibody, streptavidinalkaline phosphatase conjugate, and BCIP/NBT substrate solution. The sections were then counterstained in Nuclear Fast Red, dehydrated, cleared, and mounted with glass coverslips.

Appropriate positive, negative, and reagent controls were included for each ISH assay. The intensity and distribution of hTR were examined by two investigators on a blind basis, and discrepancies were solved after joint observations using a multiheaded microscope. Samples with $>10 \%$ of tumor cells showing a distinct nuclear staining were considered positive for hTR. The intensity was categorized as weak, moderate, or strong staining when compared with expression in germinal centers in lymphoid tissues, expression in most human epithelial tumors, or expression in the normal adult testicular tubules, respectively.

\section{Expression of TERT}

Immunohistochemical staining was performed by a sensitive peroxidase-streptavidin method with a LASB kit (DAKO Co., Ltd., Kyoto, Japan). A monoclonal antibody against TERT (Santa Cruz Biotechnology, Inc., Santa Cruz, CA) was purchased and applied after antigen retrieval in the citrate buffer. Briefly, tissue sections $4 \mu \mathrm{m}$ thick were deparaffinized in xylene and rehydrated. Endogenous peroxidase was blocked by soaking in $3 \% \mathrm{H}_{2} \mathrm{O}_{2}$ at $45^{\circ} \mathrm{C}$ for 4 minutes. The slides were placed in a Coplin jar containing citrate buffer $(2.1 \mathrm{~g} / \mathrm{L}, \mathrm{pH}$ 6.0) and heated to $120^{\circ} \mathrm{C}$ in an autoclave for 15 minutes to unmask the antigen. They were treated with a protein-blocking reagent before incubation at $4^{\circ} \mathrm{C}$ overnight with primary antibody at a 1:50 dilution. After extensive washing, the sections were incubated at room temperature for 10 minutes with biotinylated anti-mouse immunoglobulin antibodies (DAKO, Kyoto, Japan) at a 1:20 dilution and subsequently with streptavidin-biotin peroxidase complexes at a 1:25 dilution. The staining was visualized by using aminoethylcarbonate as the final chromogen. The nuclei were counterstained with hematoxylin. Cases were considered positive if $>10 \%$ of cells showed distinct cytoplasmic and/or nuclear immunostaining.

\section{Statistical Analysis}

The proportions of samples expressing telomerase activity were computed and compared with hTR and TERT expression status and selected clinicopathologic parameters, using the SPSS (Seoul, 
Korea) program. Statistical significance was established at the $P<.05$ level.

\section{RESULTS}

Clinicopathologic data are shown in Table 1, along with telomerase status.

\section{Telomerase Activity Detected by the Extract- Based TRAP-ELISA Assay}

The quality of RNA was controlled on agarose gel; the RNA extracts displayed no or partial $28 \mathrm{~S}$ and $18 \mathrm{~S}$ ribosomal RNA degradation (Fig. 1). The TRAP assay was considered valid when the absorbance units were $<0.200$ in a well with primer/dimmer/ PCR contamination control, $>0.800$ in a well of PCR/ELISA positive control, and $<0.250$ in heattreated extracts. The sample was considered telomerase positive when the net increase of absorbance was $>0.150$. We detected telomerase activity in 37 $(73 \%)$ tumors, and the results were confirmed by polyacrylamide gel electrophoresis. Telomerase activity was determined to be positive when charac- teristic 6-bp ladders as shown in the positive control lane were produced (Fig. 2). All 14 negative extracts remained negative for the enzyme products at $0.2 \mu \mathrm{g}$ protein. We created a "mixed sample" by adding the telomerase-positive cell extract to the telomerase-negative sample to check for the presence of inhibitor(s) in the telomerase-negative samples. If inhibitor(s) of Taq polymerase are not present in the sample extract, the telomerase activity in the mixed sample after the TRAP assay will be positive. All of our 14 negative extracts demonstrated visible TRAP-ladder bands when mixed with telomerase-positive control cells, indicating the lack of inhibitor of Taq polymerase in these samples. Tumors with detectable telomerase activity did not differ significantly from those without telomerase activity in respect to patients' age, gender, tumor size, location, subtype, or Lauren's classification. Telomerase activity, however, correlated well with depth of invasion $(P=.037)$ and tumor differentiation $(P=.022)$.

The positive rate from methacarn-fixed tissues was $35 \%$ of that from frozen sections (13 versus 37 ).

TABLE 1. Clinicopathologic Data of the Patients with Gastric Cancer and Expression of Telomerase, hTR, and TERT

\begin{tabular}{|c|c|c|c|c|c|c|c|c|c|}
\hline & \multicolumn{3}{|c|}{ Telomerase } & \multicolumn{3}{|c|}{ hTR } & \multicolumn{3}{|c|}{ TERT } \\
\hline & $+(n=37)$ & $-(\mathrm{n}=14)$ & $P$-value & $+(\mathrm{n}=46)$ & $-(n=15)$ & $P$-value & $+(n=40)$ & $-(\mathrm{n}=11)$ & $P$-value \\
\hline \multicolumn{10}{|l|}{ Age (years) } \\
\hline$<60(\mathrm{n}=21)$ & 16 & 5 & 0.115 & 19 & 2 & 0.456 & 14 & 7 & 0.364 \\
\hline$\geq 60(\mathrm{n}=30)$ & 21 & 9 & & 27 & 3 & & 26 & 4 & \\
\hline \multicolumn{10}{|l|}{ Sex } \\
\hline Male $(\mathrm{n}=38)$ & 27 & 11 & 0.689 & 35 & 3 & 0.443 & 29 & 9 & 0.539 \\
\hline Female $(\mathrm{n}=13)$ & 10 & 3 & & 11 & 2 & & 11 & 2 & \\
\hline \multicolumn{10}{|l|}{ Site } \\
\hline Upper $(\mathrm{n}=4)$ & 3 & 1 & 0.862 & 3 & 1 & 0.681 & 3 & 1 & 0.705 \\
\hline Middle $(\mathrm{n}=19)$ & 14 & 5 & & 18 & 1 & & 15 & 4 & \\
\hline Lower $(n=25)$ & 17 & 8 & & 22 & 3 & & 19 & 6 & \\
\hline Diffuse $(n=3)$ & 3 & 0 & & 3 & 0 & & 3 & 0 & \\
\hline \multicolumn{10}{|l|}{ Size } \\
\hline$<3 \mathrm{~cm}(\mathrm{n}=4)$ & 3 & 1 & 0.642 & 2 & 2 & 0.023 & 4 & 0 & 0.843 \\
\hline $3-5 \mathrm{~cm}(\mathrm{n}=20)$ & 16 & 4 & & 18 & 2 & & 13 & 7 & \\
\hline $5.1-8 \mathrm{~cm}(\mathrm{n}=15)$ & 9 & 6 & & 14 & 1 & & 14 & 1 & \\
\hline$>8 \mathrm{~cm}(\mathrm{n}=12)$ & 9 & 3 & & 12 & 0 & & 9 & 3 & \\
\hline \multicolumn{10}{|l|}{ Lauren's classification } \\
\hline Intestinal $(\mathrm{n}=27)$ & 20 & 7 & 0.596 & 25 & 2 & 0.745 & 21 & 6 & 0.522 \\
\hline Diffuse $(n=13)$ & 10 & 3 & & 11 & 2 & & 9 & 4 & \\
\hline Mixed $(\mathrm{n}=11)$ & 7 & 4 & & 10 & 1 & & 10 & 1 & \\
\hline \multicolumn{10}{|l|}{ Histologic type } \\
\hline Tubular $(\mathrm{n}=38)$ & 26 & 12 & 0.285 & 35 & 3 & 0.63 & 31 & 7 & 0.597 \\
\hline Signet ring cell $(n=5)$ & 4 & 1 & & 4 & 1 & & 3 & 2 & \\
\hline Papillary $(\mathrm{n}=1)$ & 1 & 0 & & 1 & 0 & & 1 & 0 & \\
\hline Others $(\mathrm{n}=7)$ & 6 & 1 & & 6 & 1 & & 5 & 2 & \\
\hline \multicolumn{10}{|l|}{ Histologic grade } \\
\hline Well differentiated $(n=10)$ & 5 & 5 & 0.022 & 8 & 2 & 0.442 & 5 & 5 & 0.219 \\
\hline Moderately differentiated $(n=18)$ & 12 & 6 & & 17 & 1 & & 17 & 1 & \\
\hline Poorly differentiated $(n=23)$ & 20 & 3 & & 21 & 2 & & 18 & 5 & \\
\hline \multicolumn{10}{|l|}{ Depth of invasion } \\
\hline $\mathrm{T} 1(\mathrm{n}=5)$ & 3 & 2 & 0.037 & 4 & 1 & 0.621 & 4 & 1 & 0.668 \\
\hline $\mathrm{T} 2(\mathrm{n}=35)$ & 23 & 12 & & 32 & 3 & & 28 & 7 & \\
\hline T3 $(\mathrm{n}=10)$ & 10 & 0 & & 9 & 1 & & 7 & 3 & \\
\hline $\mathrm{T} 4(\mathrm{n}=1)$ & 1 & 0 & & 1 & 0 & & 1 & 0 & \\
\hline \multicolumn{10}{|l|}{ Lymph node metastasis } \\
\hline No $(n=15)$ & 11 & 4 & 0.61 & 11 & 4 & 0.047 & 10 & 5 & 0.266 \\
\hline $\mathrm{N} 1(\mathrm{n}=20)$ & 15 & 5 & & 19 & 1 & & 19 & 1 & \\
\hline $\mathrm{N} 2(\mathrm{n}=16)$ & 11 & 5 & & 16 & 0 & & 11 & 5 & \\
\hline
\end{tabular}




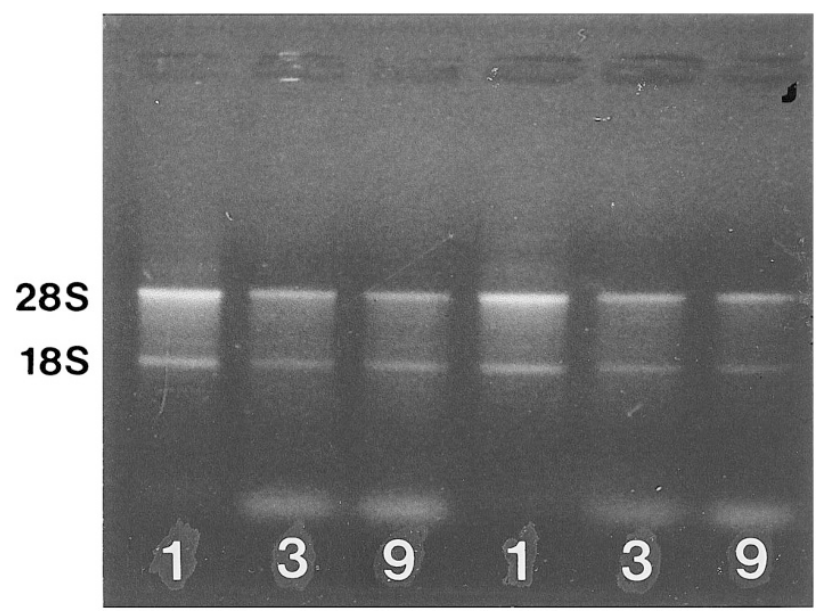

FIGURE 1. RNA quality in tumor tissues. Total RNA extracted from frozen sections (Lanes $1-3$ ) and matched methacarn-fixed tissues (Lanes 4-6) was subjected to $1 \%$ agarose gel electrophoresis. Each lane (Cases 1, 3, and 9) containing $5 \mu \mathrm{g}$ of total RNA showed $28 \mathrm{~S}$ and $18 \mathrm{~S}$ ribosomal RNA bands.

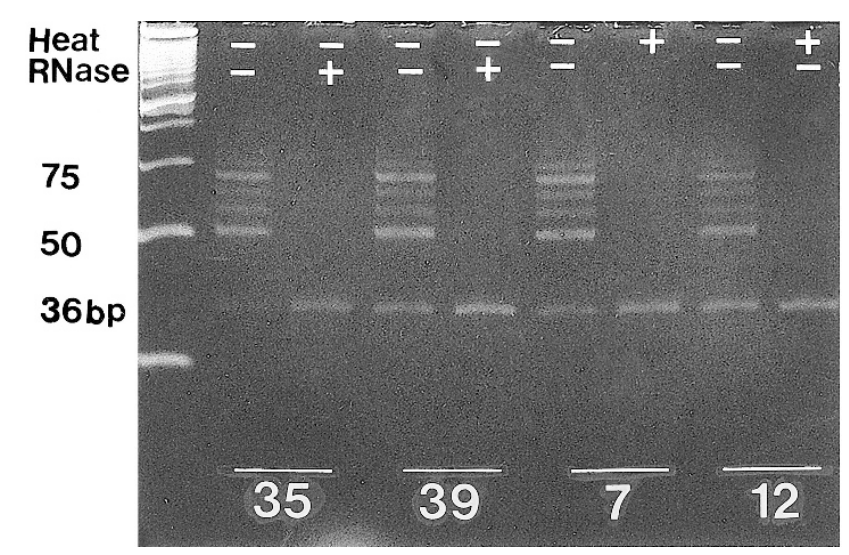

FIGURE 2. Telomerase activity in gastric cancers. Telomerase assays were carried out using extracts containing $1 \mu \mathrm{g}$ of protein from surgically resected tumor tissues with or without heat and RNase pretreatment of the extract. The PCR products were applied to a $12.5 \%$ nondenaturing polyacrylamide gel and visualized by ethidium bromide staining to confirm the results by ELISA protocol. The 36-bp internal control band is seen in every lane. Each tumor (Cases 35, 39, 7, and 12) showed characteristic 6-bp ladder signals (Lanes 2, 4, 6, and 8), which were abolished by the pretreatment of RNase A (Lanes 3 and 5). Heatinactivated samples were negative for the discernible ladder pattern (Lanes 7 and 9).

All 13 patients with telomerase activity in their methacarn-fixed tumor tissues were also positive in matched frozen samples.

\section{Telomerase RNA Expression with the Use of ISH Assay}

None of 10 samples obtained from normal adjacent tissues displayed hTR. hTR was overexpressed in $46(90 \%)$ samples, including 33 of $37(89 \%)$ telomerase-positive and 13 of $14(93 \%)$ telomerasenegative tumors ( $P=.701$; Fig. 3$)$. The staining pattern was diffuse and strong throughout the tumor. There was no difference in intensity of hTR among tumor subtypes. We found no association between hTR and tumor differentiation or depth of invasion. hTR, however, correlated with nodal metastasis $(P=.047)$ and tumor size $(P=.023)$.

\section{TERT Expression with the Use of Immunohistochemistry}

The expression of TERT was focal with a heterogeneous pattern, showing either predominantly cytoplasmic or mixed nuclear and cytoplasmic staining. It was detected in 40 (78\%) cases (Fig. 4): 30/37 $(81 \%)$ with and $10 / 14(71 \%)$ without telomerase activity $(P=.465)$. TERT expression correlated with neither hTR $(P=.301)$ nor any of the clinicopathologic parameters.

\section{DISCUSSION}

In the present study, $73 \%$ of the tumors examined had detectable telomerase activity, whereas adjacent normal tissues showed no enzyme activity. Several investigations on telomerase activity in stomach cancers demonstrated positivity ranging from 61 to $89 \%$ (31-34). Data in the literature and observations in this investigation indicate that telomerase reactivation may play a significant role in the tumorigenesis of these tumors.

Telomerase is a ribonucleoprotein, RNAdependent DNA polymerase that synthesizes TTAGGG telomeric repeat units to regulate telomere length, which in turn controls cell division (35). It can be detected in a variety of human tumors and tumor-derived cell lines by a sensitive PCR-based telomerase (TRAP) assay. This method, however, requires either fresh or frozen tissue, thus limiting retrospective sampling. Paraffin embedding is routinely used because of the ease of tissue handling and subsequent staining, as well as good preservation of morphology. If paraffin-embedded tissue retains intact RNAs and proteins, then it can be applied as a universal material source for studies of cell populations. Methacarn is a non-crosslinking protein-precipitating fixative, consisting of $60 \%$ absolute methanol, $30 \%$ chloroform, and $10 \%$ glacial acetic acid. It has been described that the individual constituents of methacarn do not seem to affect the primary structure of polynucleotides, and thus RNA molecules as well as proteins could be extracted from methacarn-fixed tissue (28-30). To the best of our knowledge, this is the first trial of TRAP assay using sections cut from methacarnfixed tissues. The tumor samples obtained for methacarn fixation were from the same area taken for frozen section as used for the TRAP assay. Frozen tissue was found to have significantly higher rates of telomerase positivity than methacarn-fixed 


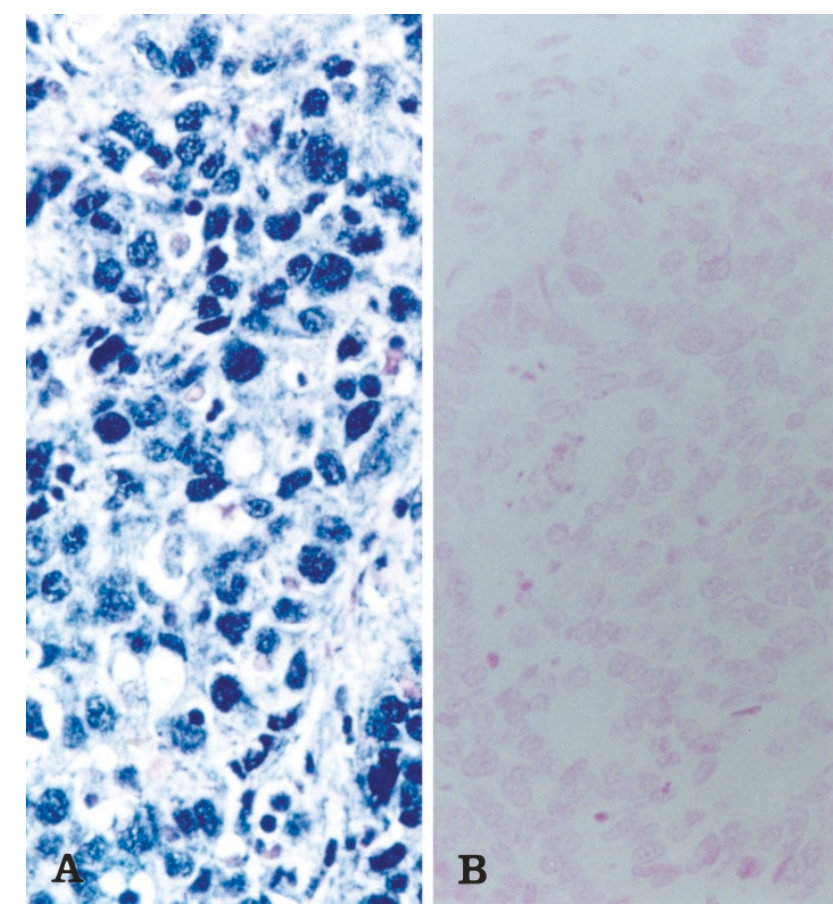

FIGURE 3. In situ hybridization for hTR expression in Case 7. A, strong expression as depicted in dark blue grains is present in the nucleus of most tumor cells. B, a negative control shows no granularity (original magnification, $200 \times$ ).

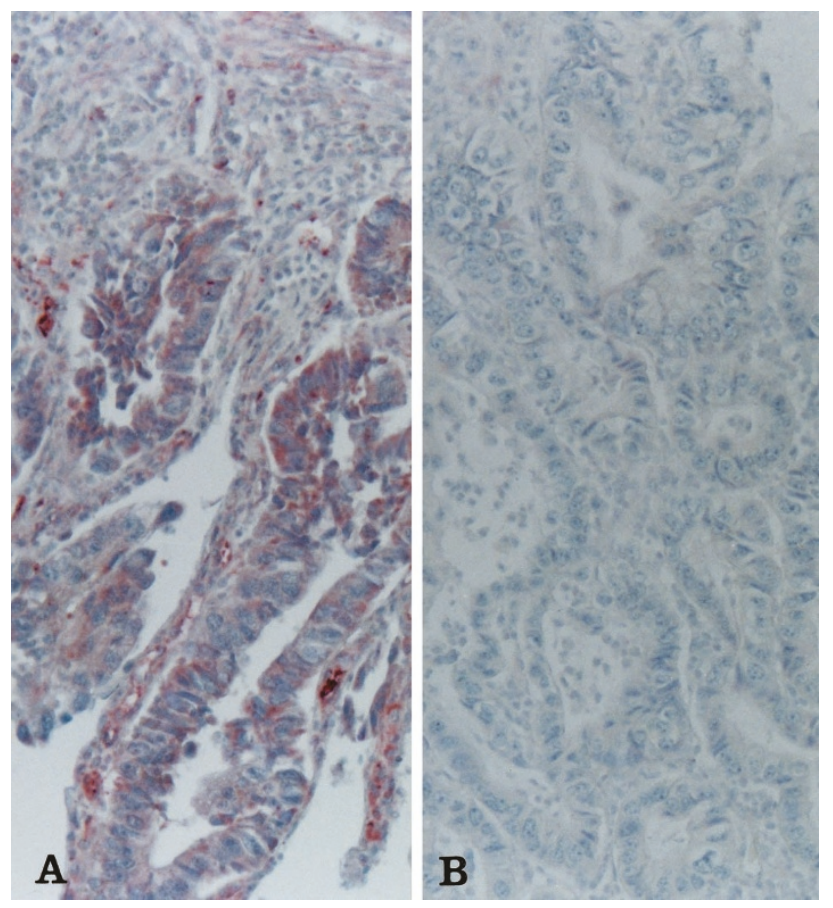

FIGURE 4. Immunohistochemistry for TERT expression in Case 50. A, intense cytoplasmic immunoreactivity is observed. B, a negative control demonstrates no reactivity (original magnification, $200 \times$ ).

tissue (73\% versus $26 \%$ ), suggesting that methacarnfixed paraffin-embedded tissues are inappropriate for the TRAP assay. The lack of telomerase activity in 24 methacarn-fixed tissues, whichcontests the presence of enzyme activity in the corresponding frozen samples, may be due to degradation of the essential telomerase-templating RNA. Because telomerase uses its RNA as a template for the synthesis of TTAGGG repeats, an active protein and an intact RNA are required (36). The RNA extracts from all the methacarnfixed samples that were examined, however, demonstrated no or partial $28 \mathrm{~S}$ and $18 \mathrm{~S}$ ribosomal RNA degradation. Another possibility to account for falsenegative results might be a reduction of active protein yield, which was observed in our methacarn-fixed paraffin-embedded tissues as compared with that from cryostat sections. This may indicate an extraction effect during fixation and subsequent paraffin embedding and deparaffinization steps. Further investigations are necessary to establish a reliable method for the analysis of telomerase activity in paraffin-embedded tissue specimens.

There have been several attempts to correlate telomerase expression with clinicopathologic variables, often with rather conflicting results. No correlation has been reported between telomerase expression and age, sex, tumor location, size, stage, histologic grade, or lymph node metastasis $(32,34)$. In contrast, it has been documented that gastric cancer patients with detectable telomerase activity had higher mortality rates than patients with no activity (33, 37). Ussekmann et al. (38) demonstrated a relationship between telomerase activity and tumor stage as well as patient survival in distal gastric cancers. Our data revealed a significant correlation of telomerase activity with depth of invasion and histologic differentiation. Thus, it is likely that reactivation of telomerase is a relatively late event during carcinogenesis and induces malignant progression in gastric cancer.

All the samples were further analyzed by ISH for an hTR component. The expression of hTR was observed in 90\% (46/51) of the tumors investigated, 13 of which exhibited hTR in the absence of telomerase expression, supporting that the presence of hTR does not reflect the presence of an active enzyme. This is consistent with the findings from a previous study by Hiyama et al. (39), who showed that telomerase activity did not parallel hTR expression. However, they found hTR in adenomas as well and thus raised the possibility of its involvement in an early stage of stomach carcinogenesis. No adenomas were included in the present study. It is of interest that hTR was present in mostly large tumors or in those with lymph node metastasis. In the literature, it was reported that there was a tendency for intensity of hTR expression to increase gradually as the cancer progressed to a more advanced stage (40). These data may indicate its possible role as a prognostic marker in gastric cancer. 
In a study of localization of TERT in various cervical lesions, the predominantly nuclear localization of TERT in low-grade squamous intraepithelial lesions contrasted with the nuclear and cytoplasmic localization of TERT in high-grade intraepithelial lesions and squamous cell carcinomas (41). The disruption of normal nuclear-targeting mechanisms for translocation of TERT to the nucleus may be responsible for these different staining patterns, as suggested. In our study on gastric cancers, TERT was detected with predominantly cytoplasmic localization, although a nuclear component was also detected. No definite conclusion on the significance of nuclear, cytoplasmic, and mixed patterns of staining is plausible at present.

As for telomerase and TERT, we confirmed that TERT expression was not always consistent with telomerase activity, although it has been reported to be associated with telomerase in various cell lines $(25,42,43)$. This discrepancy may result from sample variation; TERT staining was performed on paraffin-embedded tissue, and TRAP assay was done on frozen tissue. TERT expression was focal in most of our cases. There was, however, no better correlation between tumors with diffuse TERT staining pattern and telomerase activity. Another possible explanation could be that there is telomerase activity in some TERT-positive cells, but the levels are below the threshold of detection of even the sensitive TRAP assay. Alternatively, hTR and TERT may not be the only factors that regulate telomerase activity. Additional events that lead to telomerase activation may exist. It was postulated that there might be specific down-regulators of telomerase present in tumors. Recently, telomerase-associated or telomere-binding proteins, such as TP1/TLP1 and TRF1, were identified in mammals (44-46). These proteins, along with hTR and TERT, may interact with each other for the reactivation of telomerase. Thus, the lack of enzyme activity in our samples expressing hTR or TERT is probably due to the absence of one or more of these protein components.

In summary, our data suggest a significant role of telomerase reactivation in the tumorigenesis of gastric cancer. Reactivated telomerase and enhanced hTR may reflect the malignant potential of the tumor. Although TRAP is a sensitive and efficient PCR-based method to detect telomerase activity, its limitation is the need for either fresh or frozen tissues for the reaction. In the present study, telomerase positivity from methacarn-fixed paraffin blocks was found to be $35 \%$ of that from frozen tissues, indicating that methacarn-fixed tissue cannot as yet substitute for the frozen tissue for the assay. Improvements in the technology may provide greater applicability.

\section{REFERENCES}

1. Tahara E. Molecular mechanism of stomach carcinogenesis. J Cancer Res Clin Oncol 1993;119:265-72.

2. Ming SC. Cellular and molecular pathology of gastric carcinoma and precursor lesions: a critical review. Gastric Cancer 1998;1:31-50.

3. Yasui W, Oue N, Kuniyasu H, Ito R, Tahara E, Yokozaki H. Molecular diagnosis of gastric cancer: present and future. Gastric Cancer 2001;4:113-21.

4. Kim NW, Piatyszek MA, Prowse KR, Harley CB, West PL, Ho GM, et al. Specific association of human telomerase activity with immortal cells and cancer. Science 1994;266:2011-5.

5. Harley CB, Kim NW, Prowse KR, Weinrich SL, Hirsch KS, West MD, et al. Telomerase, cell immortality, and cancer. Vol. 66. Cold Spring Harbor, NY: Cold Spring Harbor Laboratory Press; 1994:p. 1-9

6. Zakian VA. Telomeres. Beginning to understand the end. Science 1995;270:1601-7.

7. Varon D, Jiang C, Hedican C, Dome JS, Umbricht CB, Carey LA, et al. Telomerase activity in the normal and neoplastic rat mammary gland. Cancer Res 1997;57:5605-9.

8. Levy MZ, Allsopp RC, Futcher B, Greider CW, Harley CB. Telomere end-replication problem and cell aging. J Mol Biol 1992;225:951-60.

9. Harley CB, Futcher AB, Greider CW. Telomeres shorten during aging of human fibroblasts. Nature (Lond) 1990;345:45860.

10. Allsopp RC, Chang E, Kashefi-Aazam M, Rogaev EI, Piatyszek MA, Shay JW, et al. Telomere shortening is associated with cell division in vitro and in vivo. Exp Cell Res 1995;220:194200.

11. Broccoli D, Young JW, De Lange T. Telomerase activity in normal and malignant hematopoietic cells. Proc Natl Acad Sci U S A 1995;92:9082-6.

12. Hiyama K, Hiyama E, Ishioka S, Yamakido M, Inai K, Gazdar $\mathrm{AF}$, et al. Telomerase activity in small-cell and non-small-cell lung cancers. J Natl Cancer Inst 1995;87:895-902.

13. Ahrendt SA, Yang SC, Wu L, Westra WH, Jen J, Califano JA, et al. Comparison of oncogene mutation detection and telomerase activity for the molecular staging of non-small cell lung cancer. Clin Cancer Res 1997;3:1207-14.

14. Li Z, Salovaara R, Aaltonen LA, Shibata D. Telomerase activity is commonly detected in hereditary nonpolyposis colorectal cancers. Am J Pathol 1996;148:1075-9.

15. Chadeneau C, Hay K, Hirte HW, Gallinger S, Bacchetti S. Telomerase Activity associated with acquisition of malignancy in human colorectal cancer. Cancer Res 1995;55:2533-6.

16. Brien TP, Kallakury BVS, Lowry CV, Ambros RA, Mucara PJ, Malfetano JH, et al. Telomerase activity in benign endometrium and endometrial carcinoma. Cancer Res 1997;57:2760-4.

17. Hiyama E, Gollahon L, Kataoka T, Kuori K, Yokoyama T, Gazdar AF, et al. Telomerase activity in human breast tumors. J Natl Cancer Inst 1996;88:116-22.

18. Tahara H, Nakanishi T, Kitamoto M, Nakashio R, Shay JW, Tahara E, et al. Telomerase activity in human liver tissue: comparison between chronic liver disease and hepatocellular carcinomas. Cancer Res 1995;55:2734-6.

19. Sommerfeld H, Meeker AK, Piatyszek MA, Bova GS, Shay JW, Coffey DS. Telomerase activity: a prevalent marker of malignant human prostate tissue. Cancer Res 1996;56:218-22.

20. Suehara N, Mizumoto K, Muta T, Tominaga Y, Shimura H, Kitajima S, et al. Telomerase elevation in pancreatic ductal carcinoma compared to nonmalignant pathological states. Clin Cancer Res 1997;3:993-8. 
21. Feng J, Funk WD, Wang S, Weinrich SL, Avilion AA, Chiu C, et al. The RNA component of human telomerase. Science 1995;269:1236-41.

22. Lundblad V, Blackburn EH. An alternative pathway for yeast telomere maintenance rescues est $1^{-}$senescence. Cell 1993; 73:347-60.

23. Avilion AA, Piatyszek MA, Gupta J, Shay JW, Bacchetti S, Greider CW. Human telomerase RNA and telomerase activity in immortal cell lines and tumor tissues. Cancer Res 1996;56:645-50.

24. Nakamura TM, Morin GB, Chapman KB, Weinrich SL, Andrews WH, Linger J, et al. Telomerase catalytic subunit homologs form fission yeast and human. Science 1997;277: 955-9.

25. Meyerson M, Counter CM, Eaton EN, Ellisen LW, Steiner P, Caddle SD, et al. hEST2, the putative human telomerase catalytic subunit gene, is upregulated in tumor cells and during immortalization. Cell 1997;90:785-95.

26. Piatyszek MA. Detection of telomerase activity in human cells and tumors by telomeric repeat amplification protocol (TRAP). Methods Cell Sci 1995;17:1.

27. Wright WE, Shay JW, Piatyszek MA. Modification of a telomeric repeat amplification protocol (TRAP) results in increased reliability, linearity, and sensitivity. Nucleic Acids Res 1995;23:3794-5.

28. Shibutani M, Uneyama C, Miyazaki K, Toyoda K, Hirose M. Methacarn fixation: a novel tool for analysis of gene expressions in paraffin-embedded tissue specimens. Lab Invest 2000;80:199-208.

29. Greer CE, Peterson SL, Kivat NB, Manos MM. PCR amplification from paraffin-embedded tissues. Effects of fixative and fixation time. Am J Clin Pathol 1991;95:117-24.

30. Lalani EN, Golding M, Hudson M, Chieffi G, Stamp G, Anilkumar TV, et al. Protein extraction and western blotting from methacarn-fixed tissue. J Pathol 1995;177:323-8.

31. Heine B, Hummel M, Demel G, Stein H. Demonstration of constant upregulation of the telomerase RNA component in human gastric carcinomas using in situ hybridization. J Pathol 1998;185:139-44.

32. Kameshima H, Yagihashi A, Yajima T, Kobayashi D, Hirata K, Watanabe N. Expression of telomerase-associated genes:reflection of telomerase activity in gastric cancer? World J Surg 2001:25:285-9.

33. Tahara H, Kuniyasu H, Yokozaki H, Yasui W, Shay LW, Ide T, et al. Telomerase activity in preneoplastic and neoplastic gastric and colorectal lesions. Clin Cancer Res 1995;1:124551.
34. Ahn MJ, Noh YH, Lee YS, Lee JH, Chung TJ, Kim IS, et al. Telomerase activity and its clinicopathological significance in gastric cancer. Eur J Cancer 1997;33:1309-13.

35. Crocker J. Telomeres and telomerases: intimations of immortality. Eur J Gastroenterol Hepatol 2001;13:889-90.

36. Yan P, Bosman FT, Benhattar J. Tissue quality is an important determinant of telomerase activity as measured by TRAP assay. Biotechniques 1998;25:660-2.

37. Kakeji Y, Maehara Y, Koga T, Shibahara K, Kabashima A, Tokunaga E, et al. Gastric cancer with high telomerase activity shows rapid development and invasiveness. Oncol Rep 2001;8:107-10.

38. Ussekmann B, Newbold M, Morris AG, Nwokolo CU. Telomerase acitivity and patient survival after surgery for gastric and esophageal cancer. Eur J Gastroenterol Hepatol 2001;13: 903-8.

39. Hiyama T, Yokozaki H, Kitadai Y, Tahara E, Tahara H, Ide T, et al. In situ mRNA hybridization technique for analysis of human telomerase RNA in gastric precancerous and cancerous lesions. Jpn J Cancer Res 1998;89:1187-94.

40. Rathi A, Hur K, Gazdar AF, Bae JS, Jang JJ, Kim DY. Telomerase RNA expression during progression of gastric cancer. Hum Pathol 1999;30:1302-8.

41. Frost M, Bobak JB, Gianani R, Kim N, Weinrich S, et al. Localization of telomerase hTERT protein and hTR in benign mucosa, dysplasia, and squamous cell carcinoma of the cervix. Am J Clin Pathol 2000;114:726-34.

42. Counter CM, Meyerson M, Eaton EN, Ellisen LW, Caddle SD, Haber DA, et al. Telomerase activity is restored in human cells by ectopic expression of hTERT (hEST2), the catalytic subunit of telomerase. Oncogene 1998;16:1217-22.

43. Nakayama J, Tahara H, Tahara E, Saito M, Ito K, Nakamura $\mathrm{H}$, et al. Telomerase activation by hTR in human normal fibroblasts and hepatocellular carcinomas. Nat Genet 1998; 18:65-8.

44. Harrington L, McPhail T, Mar V, Zhou W, Oulton R, Bass MB, et al. A mammalian telomerase-associated protein. Science 1997;275:973-7.

45. Nakayama J, Saito M, Nakamura H, Matsuura A, Ishikawa F. TLP1:A Gene Encoding a protein component of mammalian telomerase is a novel member of WD repeats family. Cell 1997;88:875-84.

46. Chong L, Steensel B, Broccoli D, Bromage H, Hanish J, Tempst P, et al. A human telomeric protein. Science 1995; 270:1663-7. 